\title{
An alternative method to free flap for distal leg and foot defects due to electrical burn injury: distally based cross-leg sural flap
}

\author{
Cengiz Eser, M.D., Erol Kesiktaş, M.D., Eyüphan Gencel, M.D., Emrah Efe Aslaner, M.D., Metin Yavuz, M.D.
}

Department of Plastic Surgery, Cukurova University Faculty of Medicine, Adana, Turkey

\begin{abstract}
BACKGROUND: High voltage electrical injuries can cause devastating results especially in distal extremities. Although free flaps are the golden standards for the reconstruction of these defects, sometimes local flap alternatives are more useful. One of the most favorable local flap is distally based sural flap (DBSF), which can be used in cross-leg fashion when ipsilateral extremity is affected by a high voltage electrical injury. The purpose of this study was to evaluate long term results of eleven patients who underwent a reconstruction to the lower extremity with cross-leg DBSF due to high voltage electrical burn injury between the years of 2003-2013.

METHODS: Eleven patients suffering from high voltage electrical injury from 2003 to 2013 were evaluated retrospectively. All patients were male and had deep $2^{\text {nd }}$ and $3^{\text {rd }}$ degree electrical burns on many parts of their bodies, including their lower legs and feet. Seven of the defects were located on the right limb and four of them on the left. Defects were located in the ankle area in five patients, dorsum of the foot in four patients, achilles area in one patient, and the plantar region in one patient.
\end{abstract}

RESULTS: The adaptation of flaps to the recipient site, colour, and quality were all acceptable.

CONCLUSION: As an alternative to free flaps, the cross-leg DBSF has good tissue compliance, provides tissue of adequate quantity and quality, and has low complication rates in the long term in high voltage electrical injuries of the leg and foot.

Key words: Distally-based sural flap; free flap; high-voltage electrical injury.

\section{INTRODUCTION}

Complex skin and soft tissue defect reconstruction of the lower third of the leg and foot is still a challenging problem due to insufficient donor area of local flap alternatives. ${ }^{[1-5]}$ The most common causes of leg and foot defects are electrical burns, non-healing skin wounds, chronic venous ulcers, traffic accidents, and explosive injuries. ${ }^{[6,7]}$ High voltage (>1000 volts) electrical injuries can result in mortality, and limb amputation is reported at a rate of up to $40 \%{ }^{[8-10]}$

Free tissue transfers are considered the first option for the

Address for correspondence: Cengiz Eser, M.D.

Çukurova Üniversitesi Tıp Fakültesi, Plastik Cerrahi Anabilim Dalı, 01330 Adana, Turkey

Tel: +90 322 - 3386060 / 3226 E-mail: cengizeser0I@gmail.com

Qucik Response Code Ulus Travma Acil Cerrahi Derg

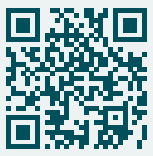

2016;22(I):46-5I

doi: $10.5505 /$ tjtes.2015.35306

Copyright 2016

TJTES reconstruction of distal lower extremity defects. ${ }^{[1,12]}$ Electrical injury and vascular problems are relative contraindications for using free flaps in the injured limb. In this instance, the problem can be overcomed by using cross-leg flaps. ${ }^{[13-16]}$ Additionally, after a free flap failure, cross-leg flaps can help repair any remaining defects. ${ }^{[17]}$

One of the most useful alternatives to free tissue transfers in the lower leg is the cross-leg distally based sural flap (DBSF). Some of the many advantages of DBSF include easy elevation; providing enough tissue for many defects in lower extremities; quick application without requiring microsurgical techniques; and sparing not only the major vessels, but also the muscles of the lower leg. ${ }^{[4,18]}$ This flap has a reliable pedicle vascularity and surface availability for covering distal lower extremity defects and can easily be used in cross-leg fashion. ${ }^{[14]}$

In this article, we present our distal leg and foot defect reconstruction with cross-leg DBSF in high voltage electrical burns as a free flap alternative. To the best of our knowledge, this is the first report on the results of cross-leg DBSF for covering lower leg and foot defects in high voltage electrical trauma patients. 


\section{MATERIALS AND METHODS}

Eleven patients suffering from high voltage electrical injury from 2003 to 2013 were evaluated retrospectively. All patients were male and had deep 2 nd and 3 rd degree electrical burns on many parts of their bodies, including their lower legs and feet. Patient age ranged between 19 and 44 years (mean, 30.5). Seven of the defects were located on the right limb and four of them on the left. After multiple and early debridements (average of two per patient), the size of the defects ranged from $8 \times 7 \mathrm{~cm}$ to $|3 \times 1| \mathrm{cm}$ (mean, 9.9x8.9) and flap sizes with skin pedicle were $7 \times 19 \mathrm{~cm}$ to $13 \times 25 \mathrm{~cm}$ (mean, $10.45 \times 23$ ). Serial debridements were done under general anesthesia until healthy tissue was seen. Vital structures such as nerves, tendons, bones, and major vessels were minimally or not debrided if they were structurally intact. Defects were located in the ankle area in five patients, dorsum of the foot in four patients, achilles area in one patient, and the plantar region in one patient.

We planned a classical cutaneous pedicled DBSF for repairing distal leg and foot defects in cross-leg fashion with a twostaged operative procedure (Figs la-d and $2 a-c$ ). The period of flap adaptation to the recipient site was 21 days and no patients had a previous delay procedure. All patients had a vascular and/or donor area problem (due to high voltage electrical contact) in the affected lower extremity. The general condition of these patients meant that a long operative procedure was not appropriate and vascular damage due to high voltage electrical contact made a free flap application too risky. All of the operations were performed by the same team. Patients' follow-up period was up to ten years. The characteristics of all patients were specified in Table I.

\section{First Operation}

Under general anesthesia, defects were debrided surgically until bleeding and viable tissue was exposed. Patient was placed in prone position and the DBSF was harvested in a subfascial plane in a rectangular shape to maintain the continuity of its own skin paddle. The axis of the flap was directed from the mid-popliteal line to the calcaneus. The sural nerve and lesser saphenous vein were included in DBSF. The size of
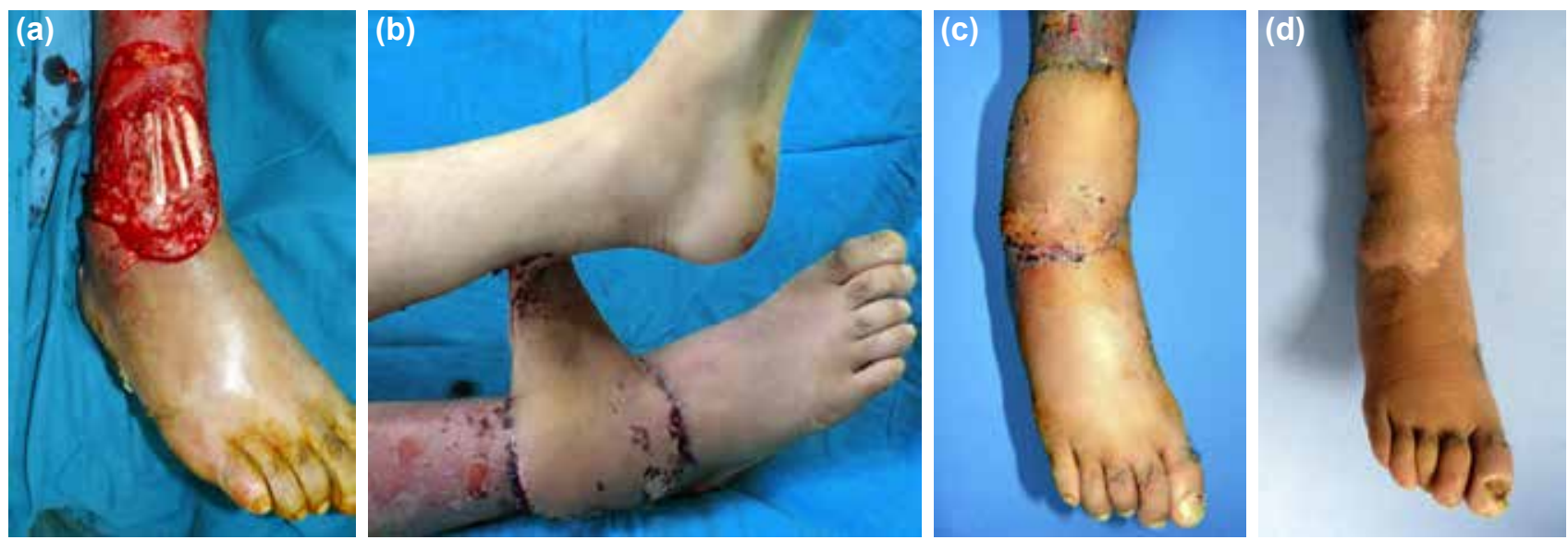

Figure 1. (a) High voltage electrical injury over the right ankle. (b) 21 days after $1^{\text {st }}$ operation, lateral view. (c) 1 month after $2^{\text {nd }}$ operation, anterior view. (d) 1 year after $2^{\text {nd }}$ operation, anterior view.
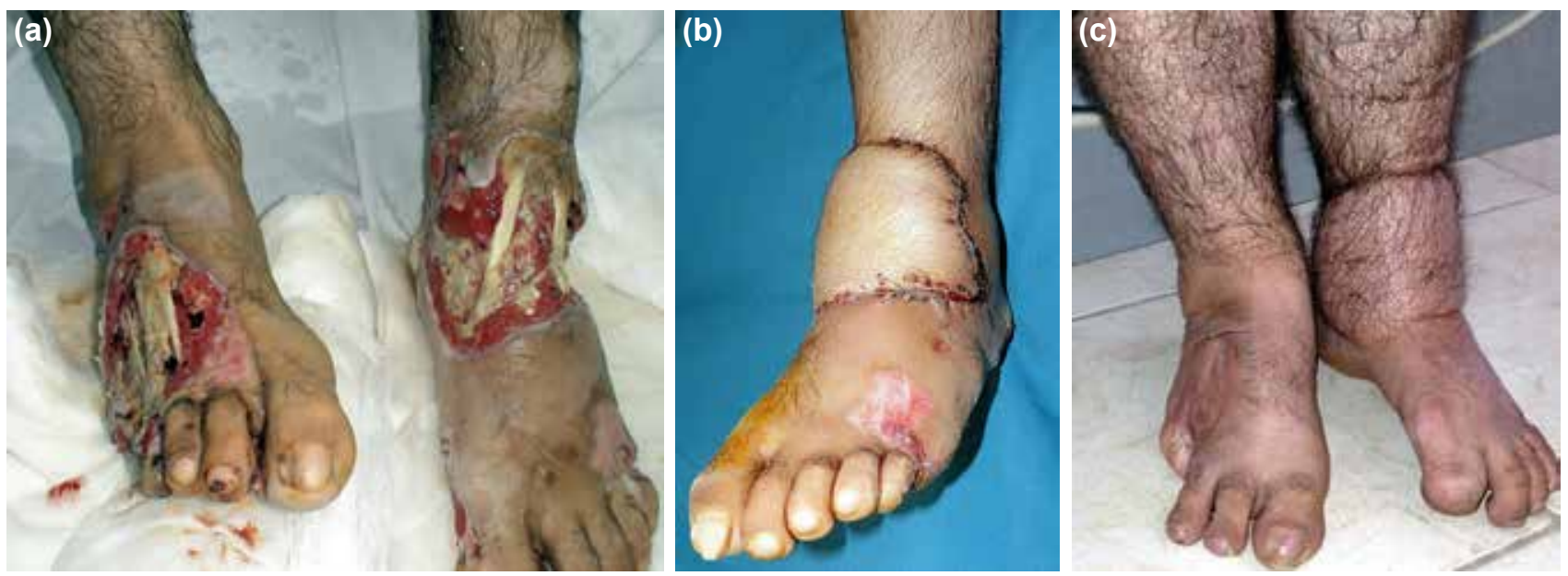

Figure 2. (a) High voltage electrical injury after debridement on left ankle joint and right dorsum of the foot. (b) One month after $2^{\text {nd }}$ operation. (c) Ten years after $2^{\text {nd }}$ operation. 


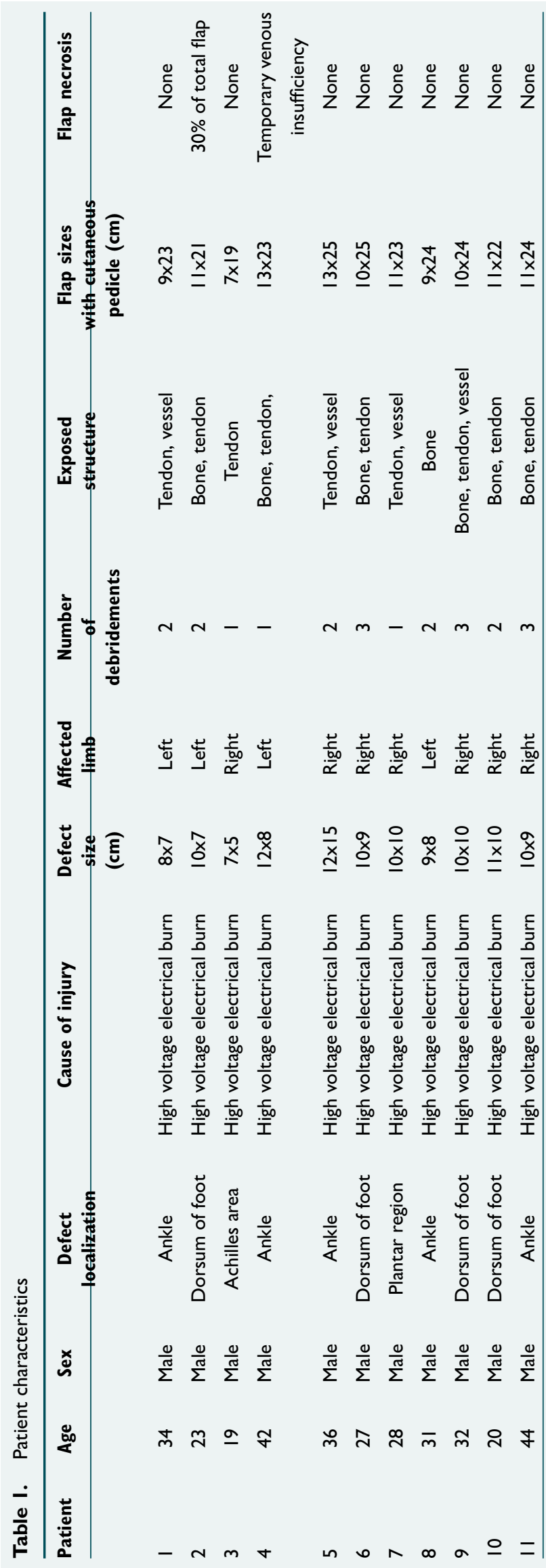

DBSF was determined based on what was needed to cover the defect on the cross leg. Pedicle base of the DBSF was preserved $5-7 \mathrm{~cm}$ above the lateral malleolus and the base width of the flap was between medial and lateral malleoli as described in the literature ${ }^{[6,13,19]}$ (Fig. 3). Then, the distal part of the neurofasciocutaneous DBSF was sutured onto the crossleg defect. The donor area of the DBSF and raw surface of skin paddle were covered with medical dressing (Epigard ${ }^{\mathrm{TM}}$; Medisave Medical Products, Wiesbaden, Germany). Both legs were fixed with elastic bandages at the end of the first operation. None of the patients applied external fixation device.

\section{Second Operation}

Pedicles were cut 21 days after Ist stage and distal part of DBSF was completely sutured to the original defect under general anesthesia. The remaining part of the skin pedicle returned to its original location on the cross-leg, resulting in only a granulated defect in the donor proximal posterior calf. This defect was closed with a split thickness skin graft.

We did not use any antithrombotic agent for flap viability after any stage of the operations. All patients had swab cultures and, if needed, culture specific antibiotherapy were administered.

\section{RESULTS}

None of the patients experienced total flap loss. Neither have they had any early or late thrombotic or joint problem after the present study. The adaptation of flaps to the recipient site, their colour, and quality were all acceptable. We saw an early stage venous insufficiency related to pedicle distortion in DBSF in patient 4, but changing extremity position solved this problem. We saw a $30 \%$ distal flap necrosis in patient 2. The necrosis was debrided and the pedicle extended via attentive dissection of its base and the legs were sutured

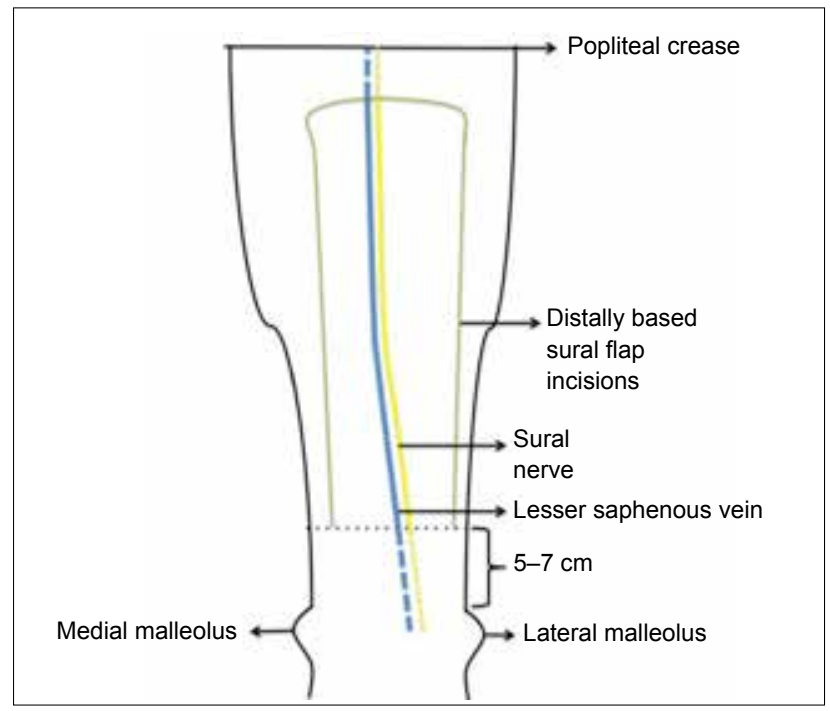

Figure 3. Schematic diagram of distally based sural flap. Dotted lines not included in flap. 
in approximation to each other. We observed numbness on the dorsum of the foot in all patients, but no one developed a disability in his or her foot. Patients were followed up from one year to ten years.

\section{DISCUSSION}

Complex lower leg injuries include exposure of vital structures such as major vessels, tendons and bones, and may lead to limb amputation and shortening. ${ }^{20]}$ Reconstruction of lower leg defects is difficult for plastic surgeons due to few available local flap options in this area. ${ }^{[1,13,19-21]}$ One of the most common causes of complex lower leg and foot defect in industrialized society is high voltage (>1000 volts) electrical injury. ${ }^{[22-24]}$ In high voltage electrical burns, the electrical source contact area (entry and exit points of body) determines the severity of the lesion. The ankle is a narrow and resistant area for electrical current in the lower leg and tissue damage is likely to be extensive in this region. ${ }^{[8]}$

An electrical injury should be debrided and covered with vascularized tissue immediately. Doing so provides the best chance to preserve vital structures and function of the limb. $[10,11,17]$ Therefore, free flap is the gold standard for the reconstruction of distal lower leg defects. It provides a way to cover the defect in all three dimensions in a single procedure. However, free flaps can also be associated with difficulties, such as sacrificing major vessels, prolonged operation time, and donor area problems, and it requires advanced surgical experience and special equipment. Finally, it is contraindicated in the case of electrical injuries because of the risk of vascular thrombosis. ${ }^{[14]}$ Posterior crural based local flaps can be used in the lower leg defect repairs when microsurgery is not considered. ${ }^{[13,25]}$ One of the most useful crural based flaps is DBSF. It has been used for the reconstruction of the distal portion of lower leg and feet defects since its original description by Masquelet et al. ${ }^{[26]}$ Basically, DBSF's blood supply comes from peroneal perforators and small extrinsic vessels around the sural nerve and some branches of the lesser saphenous vein. ${ }^{[4,6,19,27]}$ DBSF is a helpful option in many operative theatres, as it doesn't require microsurgical experience and the total operation time is no more than is required for a free flap procedure. ${ }^{[4,6,28]}$ Additionally, it is based on neurovascular and perforator vessels. Thus, using a DBSF does not affect any muscle or major vessel in the lower extremity.

Limb amputation is a catastrophic consequence of a burn injury. In the case of a high voltage electric injury, the amputation rate reported in the literature ranges from $10 \%$ to $68 \%$. ${ }^{[22,24]}$ Defect closure in the distal leg and foot prevents amputation and saves function of lower extremities.

Insufficient donor area for a local flap or serious vascular problems in the injured extremity leads us to use historical cross-leg flaps. ${ }^{[13,14,16,18]}$ Since cross-leg flaps were introduced by Hamilton in 1854 , a lot of techniques have been developed and introduced. ${ }^{[18,28,29]}$ DBSF also can be used as cross-leg fashion due to its reliable pedicle length.

Tounam et al. ${ }^{[2]}$ and Aoki S. et al. ${ }^{[30]}$ have concluded that DBSF can be harvested without the sural nerve in order to prevent disability from sural nerve loss. We believe that incorporating the sural nerve into the cross-leg DBSF provides a reliable circulation into it, but also will cause loss of feeling in dorsolateral foot. Interestingly, patients tolerated that very easily and no one complained about a disability in their cross-foot. However, harming a healthy leg sense is a disadvantage of cross-leg DBSF, which may be the result of neuropathy caused by electrical injury as Yildirim et al. have discussed. ${ }^{[1]}$

In our study, patients had varying degrees of anatomical damage on their anterior tibial or dorsalis pedis vessels due to electrical burn. There was also increased thrombosis risk in the affected extremity vessels, and the affected foot had decreased blood supply. For these reasons, we thought that using a free flap would be risky in such patients. Using a crossleg DBSF, which is prepared away from the damaged area, was a reliable option on an electrically injured leg. Additionally, large sizes of the skin and soft tissue defects tends to discourage us from using a pedicled flap from such extremity. Thus, cross-harvested local flaps could be prepared in maximum sizes and applied. In this situation, another reconstructive option could be a cross-leg free flap. But in such procedure, patients would also have to go through a difficult postoperative position for 3 weeks on top of free flap's own risks.

The sizes of the sural flap have been evaluated in several studies and ranged from approximately $3 \times 3^{[2,13,30]} \mathrm{cm}$ to $17 \times 16^{[31]}$ $\mathrm{cm}$. Our mean flap size was $10.5 \times 23 \mathrm{~cm}$ with classical skin pedicle on the base. After the second operation, the remaining part of each pedicle turned back to its previous harvested area. We chose a skin paddle owing to reliable pedicle vascularity without a delay procedure.

A meta-analysis of 50 articles, Follmar et al. ${ }^{[6]}$ have shown that in a total of 720 conventional DBSF, complete necrosis occurred in 24 cases (3.3\%) and partial necrosis in 76 cases (10.5\%). We saw only one (9.1\%) partial necrosis (patient 2 ) in our study, which may show that cross-leg DBSF doesn't increase the degree of flap necrosis due to excess rotation of pedicle or stretching it. In the present study, the necrosis was excised and the pedicle extended via more dissection of its base and the legs were sutured in approximation to each other. Additionally, we saw some early stage venous insufficiency (patient 4) related to pedicle distortion in DBSF of patient 4 , but changing extremity positions solved this problem.

In a study by Benacquista et al., ${ }^{[17]} 413$ free flaps were transferred to lower extremities and they found that 10\% of flaps failed partially or totally. After flap failure, if possible, local and distant flaps or grafts can be used for preserving the defect. Hence, after a free flap failure in the lower extremity, 
cross-leg DBSF may prove to be an extremity-saving option.

Li et al. ${ }^{[3]}$ have concluded that lowering the pivot point of DBSF can be useful for very distal foot defects. Another solution for this problem is using a cross-leg DBSF. Cross-leg DBSF can reach the distal foot by giving a proper position to the legs.

Lu et al. ${ }^{[16]}$ and Atiyeh et al. ${ }^{[18]}$ have concluded that cross-leg flaps are less technically demanding and the probability of reexploration is lower than in free flaps. Chen et al. ${ }^{[5]}$ showed that among I I 42 free flap procedure, I I 3 (9.9\%) of them had to be reexplored. Free flap operations also require sophisticated and expensive equipment. Even though cross-leg DBSF is two staged, it tends to be a cheaper procedure than a free flap treatment in distal leg lesions.

\section{Possible indications of cross-leg DBSF are;}

I. Presence of ipsilateral vascular (especially perforators), skin, or soft tissue trauma in the region proximal to the lesion due to electrical burn or secondary morbid conditions (falling, fractures etc.).

2. Insufficient surgical experience or equipment for a free flap procedure.

3. Very distal foot defects.

4. Undesirable factors such as long operative time or comorbid disorders according to patient's impaired general condition.

5. One or more free flap failures.

There are two basic difficulties when using cross-leg DBSF. One is the two-staged procedure and the other is the postoperative patient position. ${ }^{[18,32]}$ Even though awkward posture is considered intolerable, many patients can indeed tolerate this position for some weeks. Possibility of thrombotic events or joint problems due to relative immobility seems to be an important morbidity, but no patient had a thrombotic or joint problem after this study.

In conclusion, cross-leg DBSF is a reliable, easily elevated, cost effective flap. Thus, it can be applied in many operative theatres. It has good tissue compliance, provides tissue of adequate quantity and quality for leg and foot defects, and has low complication rates. DBSF is a good alternative method to free flap in high voltage electrical injuries of the lower legs.

Conflict of interest: None declared.

\section{REFERENCES}

1. Yildirim S, Akan M, Gideroglu K, Aköz T. Distally-based neurofasciocutaneous flaps in electrical burns. Burns 2002;28:379-85.

2. Touam C, Rostoucher P, Bhatia A, Oberlin C. Comparative study of two series of distally based fasciocutaneous flaps for coverage of the lower one-fourth of the leg, the ankle, and the foot. Plast Reconstr Surg 2001;107:383-92.
3. Li Y, Xu J, Zhang XZ. Lowering the pivot point of sural neurofasciocutaneous flaps to reconstruct deep electrical burn wounds in the distal foot. Burns 2013;39:808-13.

4. Gill NA, Hameed A. The sural compendium: reconstruction of complex soft-tissue defects of leg and foot by utilizing the posterior calf tissue. Ann Plast Surg 2012;69:203-8.

5. Chen KT, Mardini S, Chuang DC, Lin CH, Cheng MH, Lin YT, et al. Timing of presentation of the first signs of vascular compromise dictates the salvage outcome of free flap transfers. Plast Reconstr Surg 2007;120:187-95.

6. Follmar KE, Baccarani A, Baumeister SP, Levin LS, Erdmann D. The distally based sural flap. Plast Reconstr Surg 2007;119:138-48.

7. Jaffe DH, Peleg K; Israel Trauma Group. Terror explosive injuries: a comparison of children, adolescents, and adults. Ann Surg 2010;251:138-43.

8. Dalay C, Kesiktas E, Yavuz M, Ozerdem G, Acarturk S. Coverage of scalp defects following contact electrical burns to the head: a clinical series. Burns 2006;32:201-7.

9. Kesiktas E, Yavuz M, Gencel E, Dalay C, Acartürk S. Use of cross-leg latissimus dorsi free flap for repair of extensive lower leg electrical injury in a child. Burns 2006;32:507-10.

10. McCauley RL, Barret JP. Electrical injuries. In: Achauer BM, Eriksson E, editors. Plastic surgery indications,operations, and outcomes. 1st ed., Philedelphia: Mosby; 2000, p. 375.

11. Fischer JP, Wink JD, Nelson JA, Cleveland E, Grover R, Wu LC, et al. A retrospective review of outcomes and flap selection in free tissue transfers for complex lower extremity reconstruction. J Reconstr Microsurg 2013;29:407-16.

12. Heller L, Levin LS. Lower extremity microsurgical reconstruction. Plast Reconstr Surg 2001;108:1029-42.

13. Basile A, Stopponi M, Loreti A, Minniti de Simeonibus AU. Heel coverage using a distally based sural artery fasciocutaneous cross-leg flap: report of a small series. J Foot Ankle Surg 2008;47:112-7.

14. Bhattacharya V, Reddy GR. Retrograde perforator-based cross-leg fasciocutaneous flaps for distal leg and foot defects. Plast Reconstr Surg 2006;117:1662-4.

15. Hamdi MF, Kalti O, Khelifi A. Experience with the distally based sural flap: a review of 25 cases. J Foot Ankle Surg 2012;51:627-31.

16. Lu L, Liu A, Zhu L, Zhang J, Zhu X, Jiang H. Cross-leg flaps: our preferred alternative to free flaps in the treatment of complex traumatic lower extremity wounds. J Am Coll Surg 2013;217:461-71.

17. Benacquista T, Kasabian AK, Karp NS. The fate of lower extremities with failed free flaps. Plast Reconstr Surg 1996;98:834-42.

18. Atiyeh BS, Al-Amm CA, El-Musa KA, Sawwaf AW, Musharafieh RS. Distally based sural fasciocutaneous cross-leg flap: a new application of an old procedure. Plast Reconstr Surg 2003;111:1470-4.

19. Almeida MF, da Costa PR, Okawa RY. Reverse-flow island sural flap. Plast Reconstr Surg 2002;109:583-91.

20. Spyropoulou A, Jeng SF. Microsurgical coverage reconstruction in upper and lower extremities. Semin Plast Surg 2010;24:34-42.

21. Chang SM, Wang X, Huang YG, Zhu XZ, Tao YL, Zhang YQ. Distally based perforator propeller sural flap for foot and ankle reconstruction: a modified flap dissection technique. Ann Plast Surg 2014;72:340-5.

22. Hsueh YY, Chen CL, Pan SC. Analysis of factors influencing limb amputation in high-voltage electrically injured patients. Burns 2011;37:673-7.

23. Stefanacci HA, Vandevender DK, Gamelli RL. The use of free tissue transfers in acute thermal and electrical extremity injuries. J Trauma 2003;55:707-12.

24. Tarim A, Ezer A. Electrical burn is still a major risk factor for amputa- 
tions. Burns 2013;39:354-7.

25. Kneser U, Brockmann S, Leffler M, Haeberle L, Beier JP, Dragu A, et al. Comparison between distally based peroneus brevis and sural flaps for reconstruction of foot, ankle and distal lower leg: an analysis of donor-site morbidity and clinical outcome. J Plast Reconstr Aesthet Surg 2011;64:656-62.

26. Masquelet AC, Romana MC, Wolf G. Skin island flaps supplied by the vascular axis of the sensitive superficial nerves: anatomic study and clinical experience in the leg. Plast Reconstr Surg 1992;89:1115-21.

27. Francesco G, Kolker D, Michael HR. Modified reverse sural artery flap with improved venous outflow in lower-leg reconstruction. Ann Plast Surg 2007;59:563-5.
28. Gözü A, Ozyiğit T, Ozsoy Z. Use of distally pedicled sural fasciocutaneous cross-leg flap in severe foot and ankle trauma: a safe alternative to microsurgery in very young children. Ann Plast Surg 2005;55:374-7.

29. Quarmby CJ, Skoll PJ. The distally based, cross-leg, sural artery island flap. Plast Reconstr Surg 2001;108:798-9.

30. Aoki S, Tanuma K, Iwakiri I, Mizuno H, Ogawa R, Ozawa H, et al. Clinical and vascular anatomical study of distally based sural flap. Ann Plast Surg 2008;61:73-8.

31. Ayyappan T, Chadha A. Super sural neurofasciocutaneous flaps in acute traumatic heel reconstructions. Plast Reconstr Surg 2002;109:2307-13.

32. Long CD, Granick MS, Solomon MP. The cross-leg flap revisited. Ann Plast Surg 1993;30:560-3.

\section{ORİJINAL ÇALIŞMA - ÖZET}

\section{Elektrik yanığına bağlı distal alt ekstremite ve ayak defektleri onarımında serbest flebe alternatif bir metod: Karşı ekstremite beslemeli distal bazlı sural flep} Dr. Cengiz Eser, Dr. Erol Kesiktaş, Dr. Eyüphan Gencel, Dr. Emrah Efe Aslaner, Dr. Metin Yavuz

Çukurova Üniversitesi Tıp Fakültesi, Plastik Cerrahi Anabilim Dalı, Adana

AMAÇ: Yüksek voltajı elektrik yanıkları özellikle ekstremite distallerinde çok ciddi hasarlara neden olabilir. Her ne kadar distal alt ekstremite onarımlarında serbest flepler altın standart olsa da bazı durumlarda lokal flep uygulamaları daha avantajlı olabilir. Lokal flep seçeneklerinden sık kullanılanlardan biri distal bazlı sural fleptir (DBSF). Distal bazlı sural flep, aynı ekstremitenin yüksek voltajlı elektrik yanı̆ından ciddi derecede etkilendiği durumlarda karşı bacaktan beslemeli şekilde uygulanabilir. Bu çalışmada 2003 ile 2013 yılları arasında distal alt ekstremielerinde yüksek voltajlı elektrik yanığı oluşan ve karşı ekstremiteden hazırlanan DBSF ile rekonstrükte edilen I I hasta ve uzun dönem sonuçları değerlendirildi.

GEREÇ VE YÖNTEM: Geriye dönük olarak 2003'ten 20I3'e kadar ki sürede, yüksek voltajlı elektrik yaralanmalarından zarar gören I I hasta incelenmiştir. Tüm hastalar erkekti. Alt bacak ve ayakları da dahil vücutlarının birçok kısmında ikinci ve üçüncü dereceden elektrik yanıklar vardı. Yaraların yedisi sağ kolda ve dördü solda idi. Yaralar, beş hastanın ayak bileği kısmında, dört hastanın ayak sırtında, bir hastanın aşilinde ve bir hastanın da ayak tabanında idi.

BULGULAR: Tüm fleplerde adaptasyon, renk ve doku uyumu kabul edilebilir seviyelerdeydi.

TARTIŞMA: Yüksek voltajlı elektrik yanıklarına bağlı alt bacak ve ayak defektlerinde serbest fleplere alternatif olarak kullanılan karşı ekstremite beslemeli DBSF, doku uyumu iyi, yeterli kalite ve kantiteye sahip, uzun dönem komplikasyon oranı düşük, kullanışlı bir fleptir.

Anahtar sözcükler: Distal bazlı sural flep; serbest flep; yüksek voltajlı elektrik yanığı.

Ulus Travma Acil Cerrahi Derg 2016;22(I):46-5I doi: 10.5505/tjtes.20I5.35306 